\title{
Modular Hydrogels for Drug Delivery
}

\author{
Susana Simões $^{1,2}$, Ana Figueiras ${ }^{1,2,3}$, Francisco Veiga ${ }^{1,2}$ \\ ${ }^{1}$ Laboratory of Pharmaceutical Technology, University of Coimbra, Coimbra, Portugal; ${ }^{2}$ Pharmaceutical Studies Center (CEF), Uni- \\ versity of Coimbra, Coimbra, Portugal; ${ }^{3}$ Health Sciences Center (CICS), Faculty of Health Sciences, University of Beira Interior, \\ Covilhã, Portugal. \\ Email: rfigueiras@ff.uc.pt, fveiga@ci.uc.pt
}

Received January $7^{\text {th }}, 2012$; revised February $24^{\text {th }}$, 2012; accepted March $9^{\text {th }}, 2012$

\begin{abstract}
The development of novel drug delivery systems is an essential step toward controlled site-specific administration of therapeutics within the body. It is desirable for delivery vehicles to be introduced into the body through minimally invasive means and, these vehicles should be capable of releasing drug to their intended location at a controlled rate. Furthermore, it is desirable to develop drug delivery systems that are capable of in vivo to suffer degradation and to deliver the drug completely, avoiding the need to surgically remove the vehicle at the end of its useful lifetime. Hydrogels are of particular interest for drug delivery applications due to their ability to address these needs in addition to their good biocompatibility, tunable network structure to control the diffusion of drugs and, tunable affinity for drugs. However, hydrogels are also limited for drug delivery applications due to the often quick elution of drug from their highly swollen polymer matrices as well as the difficulty inherent in the injection of macroscopic hydrogels into the body. This paper presents an overview to the advances in hydrogels based drug delivery. Different types of hydrogels can be used for drug delivery to specific sites in the gastrointestinal tract ranging from the oral cavity to the colon. These novel systems exhibit a range of several peculiar properties which make them attractive as controlled drug release formulations. Moreover, such materials are biocompatible and can be formulated to give controlled, pulsed, and triggered drug release profiles in a variety of tissues.
\end{abstract}

Keywords: Hydrogels; Swelling; Stimuli-Environmental; Controlled Drug Deliver

\section{Introduction}

Natural polymers are derived from renewable resources widely distributed in nature [1]. These materials exhibit a large diversity of structures, different physiological functions and, may offer a variety of potential applications in the field of tissue engineering due to their various properties, such as pseudoplastic behavior, gelation ability, water binding capacity and biodegradability. Many of these polymers form hydrogels that can respond to external stimuli. Hydrogels resemble natural living tissue more than any other class of synthetic biomaterials due to their high water content and soft consistency which is similar to natural tissue [2]. Furthermore, the high water content of these materials contribute to their biocompatibility and can be used as contact lenses, linings for artificial hearts, materials for artificial skin, membranes for biosensors and drug delivery devices [2-10].

Hydrogels are polymeric materials that do not dissolve in water at physiological conditions. However, they swell considerably in aqueous medium [11] and demonstrate extraordinary capacity $(>20 \%)$ for imbibe water into their network structure. Gels that exhibit a phase transition in response to change in external conditions such as $\mathrm{pH}$, ionic strength, temperature and, electric currents are known as "stimuli-responsive" or "smart" gels [12]. Being insoluble, these three-dimensional hydrophilic networks can retain a large amount of water that contributes to their good blood compatibility and maintains a certain degree of structural integrity and elasticity [13]. This phenomenon can be explained by the presence of hydrophilic functional groups in their structure, such as $-\mathrm{OH}$, $-\mathrm{COOH},-\mathrm{CONH}_{2}$, and $-\mathrm{SO}_{3} \mathrm{H}$, capable of absorbing water without undergoing dissolution. Despite these many advantageous properties, hydrogels also have several limitations. The low tensile strength of many hydrogels limits their use in load-bearing applications and can result in the premature dissolution or flow away of the hydrogel from a targeted local site [14]. However, this limitation may not be important in some typical drug delivery applications (e.g. subcutaneous injection). In the case of hydrophobic drugs, the quantity and homogeneity of drug loading into the hydrogel may be limited. On the other hand, the high water content and large pore sizes of the most hydrogels often result in relatively rapid drug release, over a few hours to a few days. 
The present review addresses recent important research developments, which have focused in hydrogel systems. Actually, the literature is exhaustive on general aspects about hydrogels. However, the article intends to concentrate on the hydrogel applications that are responsive to $\mathrm{pH}$ and temperature with particular emphasis on the drug delivery. Each of the next issues intends to summarize the practical use of hydrogel-based drug delivery therapies for clinical use.

\section{Characterization and Network Structure}

Hydrogels can be designed to have some specifications, such as swelling and mechanical characteristics, justifying their variety of biomedical applications, from contact lenses to controlled-release drug delivery and tissue engineering $[15,16]$. They can be prepared from natural and synthetic polymer materials [17] and classified using various criteria depending on their preparation method and physicochemical properties (Table 1). Natural polymers, such as proteins [18], polysaccharides [19], and deoxyribonucleic acids (DNAs) are cross-linked by either physical or chemical bonds, and synthetic hydrogels can be easily prepared by cross-linking polymerization of synthetic monomers [20]. In addition, natural polymers can be combined with synthetic polymers to obtain different properties in the same hydrogel [21]. For example, the biodegradable property of natural polymers has been combined with several functionalities of synthetic polymers to give new functional hydrogels [22,23]. Numerous monomers and cross-linking agents have been used for the synthesis of hydrogels with wide range of chemical compositions [24].

Hydrogels, particularly, those intended for application in drug delivery and biomedical purposes are required to have acceptable biodegradability and biocompatibility, relevant requisites on the development of novel synthesis and cross-linking methods to design the desired products. Thus, a great variety of cross-linking approaches have been developed to prepare hydrogels for each particular application [41]. In the polymeric network, hydrophilic domains are present, which are hydrated in an aqueous environment, creating the hydrogel structure. As the term "network" implies cross-link, this kind of linkage have to be present to avoid dissolution of the hydrophilic polymer chains into the aqueous phase. A great variety of chemical and physical methods to establish cross-linking have been used to prepare hydrogels [41]. In chemically cross-linked gels, covalent bonds are present between different polymer chains. In physically cross-linked gels, dissolution is prevented by physical interactions, which exist between different polymer chains. The network structure of a hydrogel will determine its properties as a drug delivery device.
Table 1. Hydrogels classification.

\begin{tabular}{|c|c|c|}
\hline Classification & Contents & Ref. \\
\hline Origin & $\begin{array}{ll}\text { - } & \text { Natural } \\
\text { - } & \text { Synthetic }\end{array}$ & [17] \\
\hline $\begin{array}{l}\text { Ionic charge } \\
\text { (based on the } \\
\text { nature of the } \\
\text { pendent groups) }\end{array}$ & $\begin{array}{ll}\dot{\cdot} & \text { Neutral } \\
\dot{*} & \text { Anionic } \\
\dot{\text { - }} & \text { Cationic } \\
\text { Ampholytic }\end{array}$ & [25-27] \\
\hline $\begin{array}{l}\text { Water content } \\
\text { or degree } \\
\text { of swelling }\end{array}$ & $\begin{array}{ll}\text { - } & \text { Low swelling } \\
\text { - } & \text { Medium swelling } \\
\text { - } & \text { High swelling } \\
\text { - } & \text { Superabsorbent }\end{array}$ & [28] \\
\hline $\begin{array}{l}\text { Network } \\
\text { Structure } \\
\text { (Porosity) }\end{array}$ & $\begin{array}{ll}\cdot & \text { Nonporous } \\
\cdot & \text { Microporous } \\
\cdot & \text { Macroporous } \\
\cdot & \text { Superporous }\end{array}$ & {$[29,30]$} \\
\hline $\begin{array}{l}\text { Network } \\
\text { morphology }\end{array}$ & $\begin{array}{ll}\text { - } & \text { Amorphous } \\
\text { - } & \text { Semicrystaline } \\
\text { Hydrogen bonded } \\
\text { structures } \\
\text { - } & \text { Super molecular } \\
& \text { structures } \\
\text { - } & \text { Hydrocolloidal } \\
& \text { agregates }\end{array}$ & {$[31,32]$} \\
\hline $\begin{array}{l}\text { Cross-linking } \\
\text { method }\end{array}$ & $\begin{array}{ll}\cdot & \text { Chemical } \\
\text { (or covalent) } \\
\text { - } & \text { Physical } \\
& \text { (or noncovalent) }\end{array}$ & [33] \\
\hline $\begin{array}{l}\text { Component } \\
\text { (based on the } \\
\text { method of } \\
\text { preparation) }\end{array}$ & $\begin{array}{ll}\text { - } & \text { Homopolymer } \\
\text { - } & \text { Copolymer } \\
\text { - } & \text { Multipolymer } \\
\text { - } & \text { Interpenetrating }\end{array}$ & [34] \\
\hline $\begin{array}{l}\text { Function (based } \\
\text { on the } \\
\text { organization of } \\
\text { the monomers) }\end{array}$ & $\begin{array}{ll}\text { - } & \text { Biodegradable } \\
\text { or Non-biodegradable } \\
\text { - } & \text { Stimuli responsive } \\
\text { - } & \text { Superabsorbent }\end{array}$ & {$[33,35,36]$} \\
\hline $\begin{array}{l}\text { Mechanism } \\
\text { controlling } \\
\text { the drug release }\end{array}$ & $\begin{array}{ll}\text { - } & \text { Diffusion controlled } \\
\text { release systems } \\
\text { - } & \text { Swelling controlled } \\
\text { release systems } \\
\text { - } & \text { Chemically controlled } \\
\text { release systems } \\
\text { - } & \begin{array}{l}\text { Environment } \\
\text { responsive systems. }\end{array}\end{array}$ & {$[14,37-40]$} \\
\hline
\end{tabular}

Generally, hydrogels are characterized for their morphology, swelling properties and elasticity [39]. Morphology is indicative of their porous structure. Swelling determines the release mechanism of the drug from the swollen polymeric mass while elasticity affects the mechanical strength of the network and determines the stability of these drug carriers [37]. Table 2 highlights some of the important methods to prepare and measure hydrogels and some crucial characterization parameters.

\section{Responsive Hydrogels}

Over the last thirty years, researches have dedicated much attention to the so called "stimuli-responsive" or 
Table 2. Hydrogels preparation and characterization parameters.

\begin{tabular}{|c|c|c|}
\hline Preparation & $\begin{array}{c}\text { Characterization } \\
\text { Parameter }\end{array}$ & $\begin{array}{l}\text { Techniques of } \\
\text { measurement }\end{array}$ \\
\hline $\begin{array}{l}\text { Isostatic ultra } \\
\text { high pressure } \\
\text { (IUHP) }\end{array}$ & $\begin{array}{l}\text { Morphology/ } \\
\text { Network pore } \\
\text { size }\end{array}$ & $\begin{array}{ll}\text { - } & \text { Quasi-elastic } \\
& \text { laser-light scattering; } \\
\text { - } & \text { Electron microscopy; } \\
\text { - } & \text { Mercury morosimetry; } \\
\text { - } & \text { Rubber elasticity } \\
& \text { measurements; } \\
\text { - } & \text { Equilibrium swelling } \\
& \text { experiments. }\end{array}$ \\
\hline $\begin{array}{l}\text { Use of cross } \\
\text { linkers }\end{array}$ & & $\begin{array}{l}\text { - Dimensional changes } \\
\text { with time; } \\
\text { - Aqueous medium or }\end{array}$ \\
\hline $\begin{array}{l}\text { Use of water } \\
\text { and critical } \\
\text { conditions of } \\
\text { drying }\end{array}$ & $\begin{array}{l}\text { Degree of } \\
\text { swelling }\end{array}$ & $\begin{array}{l}\text { medium specific } \mathrm{pH} \text {; } \\
\text { Volume or mass } \\
\text { degree of swelling; } \\
\text { - Equilibrium water } \\
\text { content. }\end{array}$ \\
\hline $\begin{array}{l}\text { Use of gelling } \\
\text { agents }\end{array}$ & $\begin{array}{l}\text { Cross-linking } \\
\text { and mechanical } \\
\text { strength }\end{array}$ & $\begin{array}{l}\text { Ultimate compressive } \\
\text { strength, change in } \\
\text { polymer solubility } \\
\text { with time. }\end{array}$ \\
\hline $\begin{array}{l}\text { Use of } \\
\text { nucleophilic } \\
\text { substitutio } \\
\text { reaction }\end{array}$ & Drug diffusion & $\begin{array}{ll}\text { - } & \text { Membrane } \\
\text { permeability, } \\
\text { - }\end{array}$ \\
\hline \multirow[t]{2}{*}{$\begin{array}{l}\text { Use of } \\
\text { irradiation and } \\
\text { freeze thawing }\end{array}$} & & $\begin{array}{ll}\text { spectroscopy, } \\
\text { - Scanning electron } \\
\text { microscopy (SEM), } \\
\text { Quasi-elastic laser } \\
\text { light scattering. }\end{array}$ \\
\hline & $\begin{array}{c}\text { Drug } \\
\text { distribution }\end{array}$ & $\begin{array}{ll}\text { - } & \text { FTIR microscopy, } \\
\text { - } & \text { SEM }\end{array}$ \\
\hline
\end{tabular}

“environment-sensitive" polymers. This kind of polymers are the ability to answer concerning to small physiccal or chemical stimuli. Hydrogels can exhibit dramatic changes in their swelling behavior, network structure, permeability or mechanical strength in response to different internal or external stimuli [42]. Figure 1 shows various stimuli that have been explored for modulating drug delivery. External stimuli are produced with the help of different stimuli-generating devices, whereas internal stimuli are produced within the body to control the structural changes in the polymer network and to exhibit the desired drug release [43]. Most of the time drug release is observed during the swelling of the hydrogel. However, a few instances drug release was observed during syneresis of the hydrogel as a result of a squeezeing mechanism [44].

Such systems are evidently attractive for biotechnology and medicine studies [24,45-49]. Versatile stimuli-sensitive controlled release systems can be fabricated, provided that the hydrogels are well designed to change

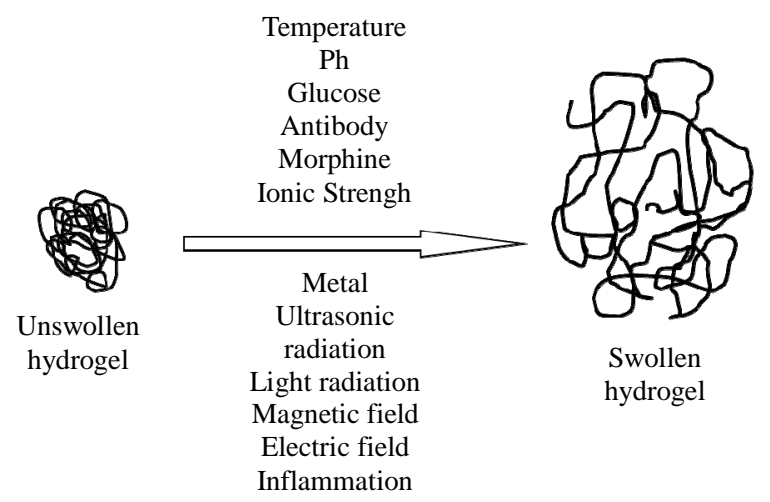

Figure 1. Representation of hydrogels stimuli responsive swelling.

their configuration in response to these stimuli based on almost infinitely available mechanisms [50]. Typical examples of environmental-sensitive hydrogels are listed in Table 3.

For a polymer system to become "sensitive", (i.e. capable of responding strongly to slight changes provided from the external medium), a first-order phase transition, accompanied by a sharp decrease in the specific volume of their macromolecules must occur. The theoretical foundations of such processes were stated by Flory and collaborators [51].

One of the main conditions for the manifestation of the critical phenomena in the swollen polymer networks or linear macromolecules is the presence of "poor" solvent [52]. In such solvent, the forces of attraction between the segments of the polymer chain may overcome the repulsion forces associated with the excluded volume, which leads to the collapse of the polymer chain [45].

The responsive hydrogels are highly sensitive to changes in the environment and have been used in several applications, such as biosensors [46,53-55], superabsorbent polymers [56-58], site-specific drug delivery systems [46,53,54,59-69], emerging nanoscale technologies [70-77] and tissue engineering [16,78-89]. Other important area for the use of polyelectrolytic hydrogels is bioand mucoadhesive drug delivery systems [90-92]. Responsive hydrogels are unique concerning many different mechanisms for drug release and a lot of many different types of release systems based on these materials are formulated. For instance, in most cases drug release occurs when the gel is highly swollen or swelling and is typically controlled by the rate of swelling, the drug diffusion, or a coupling of swelling and diffusion.

Other interesting characteristic of many responsive hydrogels is that the mechanism causing the network structural changes can be entirely reversible. This behavior is depicted in Figure 2 for a $\mathrm{pH}$ - or temperature-responsive hydrogels. The ability of these systems to exhibit rapid changes in their swelling behavior and pore 
Table 3. Various environmental stimuli used for triggering drug release from responsive hydrogels.

\begin{tabular}{|c|c|c|c|c|c|}
\hline & $\begin{array}{l}\text { Environmental } \\
\text { stimuli }\end{array}$ & Mechanism & Applications & Polymers & References \\
\hline \multirow{6}{*}{$\frac{\bar{J}}{\frac{5}{2}}$} & Temperature & $\begin{array}{l}\text { Competition between } \\
\text { hydrophobic interaction } \\
\text { and hydrogen bonding. }\end{array}$ & $\begin{array}{l}\text { On/off drug release, } \\
\text { squeezing device. }\end{array}$ & $\begin{array}{l}\text { PNIPAAm; } \\
\text { PDEAAm }\end{array}$ & [93-100] \\
\hline & Electrical signal & $\begin{array}{l}\text { Reversible swelling or } \\
\text { deswelling in the presence } \\
\text { of electrical field. }\end{array}$ & $\begin{array}{l}\text { Actuator, artificial } \\
\text { muscle, on/ off } \\
\text { drug release. }\end{array}$ & $\begin{array}{l}\text { Polyelectrolytes } \\
\text { PHEMA }\end{array}$ & [101-104] \\
\hline & Light & $\begin{array}{l}\text { Temperature change via } \\
\text { the incorporated } \\
\text { photosensitive molecules; } \\
\text { dissociation into ion pairs } \\
\text { by UV irradiation. }\end{array}$ & $\begin{array}{l}\text { Optical switches, } \\
\text { ophthalmic } \\
\text { drug delivery. }\end{array}$ & $\begin{array}{l}\text { Copolymer of } \\
\text { PNIPAAm }\end{array}$ & {$[55,105-108]$} \\
\hline & Magnetic fields & $\begin{array}{l}\text { Applied magnetic field causes } \\
\text { pore in gel and swelling } \\
\text { followed by drug release. }\end{array}$ & $\begin{array}{l}\text { Controlled drug } \\
\text { delivery while the } \\
\text { magnetic particles, } \\
\text { used formedical } \\
\text { therapy. }\end{array}$ & $\begin{array}{l}\text { EVAc, Copolymer } \\
\text { of PNIPAAm }\end{array}$ & [109-114] \\
\hline & $\begin{array}{l}\text { Ultrasonic } \\
\text { irradiation }\end{array}$ & $\begin{array}{l}\text { Temperature increase causes } \\
\text { release of drug. }\end{array}$ & Drug delivery. & EVAh & [115-118] \\
\hline & Ionic strength & $\begin{array}{l}\text { Change in concentration of } \\
\text { ions inside the gel causes } \\
\text { swelling and release of drug. }\end{array}$ & $\begin{array}{l}\text { Biosensor for glucose, } \\
\text { used for medical } \\
\text { therapy. }\end{array}$ & Nonionic PNIPAAm & [119-121] \\
\hline \multirow{2}{*}{ שี } & $p H$ & $\begin{array}{l}\text { Ionization of polymer chain } \\
\text { upon } \mathrm{pH} \text { change; } \mathrm{pH} \text { change } \\
\text { causes swelling } \\
\text { and release of drug. }\end{array}$ & $\begin{array}{l}\text { pH-dependent oral } \\
\text { drug delivery. }\end{array}$ & PAA, PDEAEM, & {$[52,121-125]$} \\
\hline & Chemical agents & $\begin{array}{l}\text { Formation of charge-transfer } \\
\text { complex causes swelling and } \\
\text { release of drug. }\end{array}$ & Controlled drug delivery. & $\begin{array}{l}\text { Chitosan -PEO, } \\
\text { polyelectrolytes }\end{array}$ & {$[62,119,126,127]$} \\
\hline \multirow{2}{*}{ 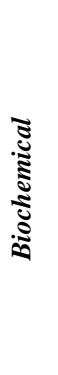 } & Glucose & $\begin{array}{l}\text { pH change causes by glucose } \\
\text { oxidase; reversible interaction } \\
\text { between glucose-containing } \\
\text { polymers and Concanavalin } \\
\text { A; reversible sol-gel } \\
\text { transformation. }\end{array}$ & $\begin{array}{l}\text { Self-regulated insulin } \\
\text { delivery. }\end{array}$ & $\begin{array}{l}\text { EVAc; pH-sensitive } \\
\text { hydrogels; } \\
\text { Concanavalin } \\
\text { A-grafted polymers. }\end{array}$ & {$[27,36,128-133]$} \\
\hline & Antigen & $\begin{array}{l}\text { Competition between } \\
\text { polymer-grafted antigen } \\
\text { and free antigen. }\end{array}$ & $\begin{array}{l}\text { Modulated drug release } \\
\text { in the presence of a } \\
\text { specific antigen; sensor } \\
\text { for immunoassay and } \\
\text { antigen. }\end{array}$ & $\begin{array}{l}\text { Semi-IPN with } \\
\text { grafted antibodies } \\
\text { or antigens. }\end{array}$ & {$[48,134,135]$} \\
\hline
\end{tabular}

Note PNIPAAm = poly $(N$-isopropylacrylamide $)$ PDEAAm = poly $\left(N, N^{\prime}\right.$-diethylacrylamide $)$ PHEMA = poly $(2$-hydroxyethyl methacryate $)$ : EVAc = ethylene-co-vinyl acetate; EVAh = ethylene-co-vinyl alcohol; PEO = polyethylene oxide; IPN = interpenetrating network.

structure in response to changes in environmental conditions lend to these materials favorable characteristics as carriers for delivery of bioactive agents, including peptides and proteins. This type of behavior may allow these materials to serve as self-regulated and pulsatile drug delivery systems.

\section{Applications of Hydrogels in Drug Delivery}

Hydrogels have been extremely useful in biomedical and pharmaceutical applications due to their unique swelling properties and their structure. Based on their functionalities, these biomaterials can be an excellent candidate for controlled drug release systems, bioadhesive or targetable devices and, self-regulated release formulations. According to the delivery administration, hydrogel-based devices can be used for oral, nasal, ocular, rectal, vaginal, epidermal and subcutaneous applications $[50,137]$.

Controlled-release or controlled-delivery systems are intended to provide the drug at a predetermined temporal and/or spatial way within the body to fulfill the specific therapeutic needs. Hydrogels, among the different controlled-release systems exploited so far, have particular 


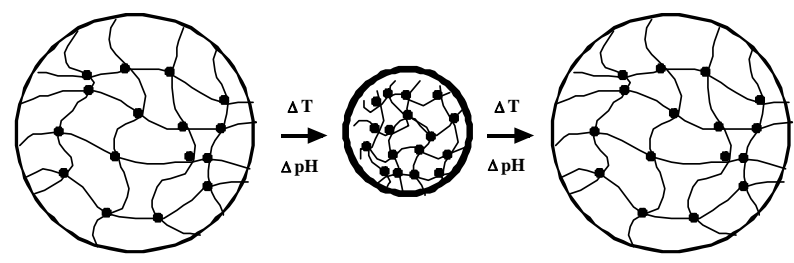

Figure 2. Swollen temperature- and pH-sensitive hydrogels may exhibit an abrupt change from the expanded (left) to the collapsed (syneresed) state (center) and then back to the expanded state (right), adapted from [136].

properties which make them to be potentially considered as one of the ideal future controlled-release systems. There are two major categories of hydrogel based delivery systems: 1) time-controlled systems and 2) stimuliinduced release systems [40,138]. Sensitive hydrogel systems are developed to deliver their content(s) in response to a fluctuating condition in a way that desirably coincides with the physiological requirements at the right time and proper place [40]. Despite the huge attraction centered towards the novel drug delivery systems based on the environment-sensitive hydrogels in the past and current times, these systems have disadvantages of their own. The most considerable drawback of stimuli-sensitive hydrogels is their significantly slow response time, with the easiest way to achieve fast-acting responsiveness being to develop thinner and smaller hydrogels which, in turn, bring about fragility and loss of mechancal strength in the polymer network and the hydrogel device itself [48].

Controlled drug delivery can be used to achieve some objectives. That is:

- Sustained constant concentration of therapeutically active compounds in the blood with minimum fluctuations;

- Predictable and reproducible release rates over a long period of time;

- Protection of bioactive compounds having a very short half-time;

- Elimination of side-effects, waste of drug and frequent dosing;

- Optimized therapy and better patient compliance;

- Solution for drug stability problems.

Hydrogels have a unique characteristics combination that makes them useful in drug delivery applications. Due to their hydrophilicity, hydrogels can imbibe large amounts of water $(>90 \%, \mathrm{w} / \mathrm{v})$. Therefore, the molecular release mechanisms from hydrogels are very different from hydrophobic polymers. Both simple and sophisticated models have been previously developed to predict the release of a drug from a hydrogel device as a function of time. These models are based on the rate limiting step for controlled release and are therefore categorized as follows [136]:
1) Diffusion-controlled systems:

Matrix (monolithic systems)

Reservoir (membrane systems)

2) Swelling-controlled systems:

Solvent-activated systems

Osmotically controlled systems

3) Chemically controlled systems:

Bioerodible and biodegradable systems

Pendent chain systems

Diffusion-controlled is the most widely applicable mechanism for describing drug release from hydrogels. This property can be described by Fick's law, according with Equations (1) and (2) [139],

$$
\begin{gathered}
J=-D\left(\frac{\mathrm{d} c}{\mathrm{~d} x}\right) \\
\frac{\partial c}{\partial t}=-D\left(\frac{\partial^{2} c}{\partial x^{2}}\right)
\end{gathered}
$$

Assuming a binary system, $t, c, J$, and $D$ represent the time, the solute concentration, mass flux and the diffusion mutual differential coefficient, respectively.

In reservoir devices the drug is contained in a core which is surrounded by a rate-controlling polymeric membrane. Drug transport from the core through the external polymer membrane occurs by dissolution at one interface of the membrane and diffusion driven by a gradient in thermodynamic activity. Drug transport can be described by Fick's first law. If the activity of the drug in the reservoir remains constant and infinite sink conditions are maintained, the drug release rate may be continued to be constant and can be predicted since it depends on the membrane permeability and device configuration. Then, drug release will be independent of time and, zero-order kinetics can be achieved. Drug diffusivities is generally determined empirically or estimated a priori using free volume, hydrodynamic or obstructtion-based theories [140].

Swelling-controlled release occurs when diffusion of drug is faster than hydrogel swelling. The modeling of this mechanism usually involves moving boundary conditions where molecules are released at the interface of rubbery and glassy phases of swollen hydrogels [141]. The release of many small molecule drugs from hydroxypropyl methylcellulose (HPMC) hydrogel tablets is commonly modeled using this mechanism [141,142]. In swelling-controlled devices, the drug can be released following two different mechanisms: diffusion and relaxation of polymer chains, which occur at the glassyrubbery interface. Ritger and Peppas $[143,144]$ proposed a simple equation to determine the relative importance of diffusion and macromolecular relaxation on the overall drug delivery process, 


$$
\frac{M_{t}}{M_{\infty}}=k t^{n}
$$

$M_{\tau}$ and $M_{\infty}$ are the amounts of drug released at time $t$ and at the equilibrium, respectively. $k$ is a proportionality constant and $n$ is the diffusional exponent.

Ritger and Peppas [143,144] introduced this exponenttial equation to describe the drug release behavior from polymeric matrixes and, analysis of the Fickian and nonFickian diffusional behavior relative to the value of the exponent $n$ was performed. Diffusional exponent values for planar, cylindrical and spherical drug release systems were related with the mechanism of delivery.

Chemically-controlled release is used to describe drug release determined by reactions occurring within a delivery matrix. The most common reactions that occur within hydrogel delivery systems are cleavage of polymer chains via hydrolytic or enzymatic degradation or reversible/ irreversible reactions occurring between the polymer network and the drug released [145]. Under certain conditions, the surface or bulk erosion of hydrogels will control the rate of drug release. Alternatively, if drug-binding moieties are incorporated in the hydrogels, the binding equilibrium can determine the drug release rate. Chemically-controlled release can be further categorized according to the type of chemical reaction occurring during drug release. Generally, the delivery of encapsulated or tethered drugs can occur through the degradation of pendant chains or during surface-erosion or bulk-degradation of the polymer backbone [40]. In pendant chain systems, the drug is covalently attached to a polymer backbone. The bond between the drug and the polymer is labile and can be broken by hydrolysis or enzymatic degradation.

In erodible drug delivery systems the release of the drug is controlled by the dissolution or degradation of the polymer. Contrary to pendant chain systems, the drug diffuses from erodible systems. Depending on whether diffusion or polymer degradation controls the release rate, the drug is released following different mechanisms. If erosion of the polymer is much slower than the diffusion of the drug through the polymer, then drug release can be treated as a diffusion controlled process. If the diffusion of the drug from the polymer matrix is very slow, then polymer degradation or erosion is the rate-controlling step. Two different types of erodible polymers can be found: hydrophilic and hydrophobic [136]. Hydrophilic erodible polymers are completely permeated by water and they undergo a bulk erosion process. Erosion takes place throughout the polymer matrix. Hydrophobic erodible polymers can experience bulk or surface erosion. In bulk erosion, degradation occurs throughout the bulk of the polymer and generally the analysis of the drug release kinetics is complex since it comprises erosion and diffusion [136].

In all routes of drug administration, oral administration has been considered to be most convenient, and hence the majority of dosage forms are designed for oral drug delivery. Different types of hydrogels can be used for delivery of drugs to certain areas in the gastrointestinal tract ranging from the oral cavity to the colon, as shown in Figure 3.

The next section summarizes the applications of hydrogels in different routes of administration, including its challenges and current status of development.

\subsection{Oral Administration}

Oral drug delivery is the most desirable and preferred method of therapeutic agents administration. In addition,

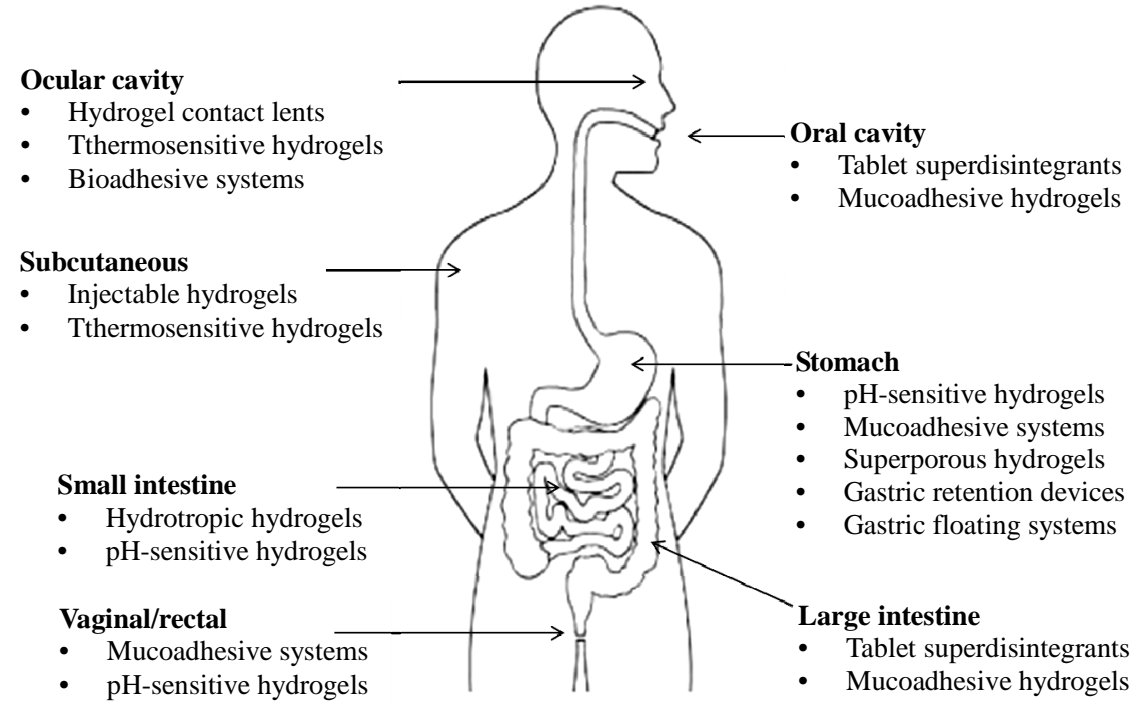

Figure 3. Tissue localization of hydrogel-based drug delivery systems, adapted from [20]. 
the oral therapy is generally considered as the first strategy investigated in the discovery and development of new drug entities and pharmaceutical formulations, mainly because the patient acceptance, the convenience in administration, and the cost-effective manufacturing process. Oral drug delivery using controllable hydrogels has attracted considerable attention in the past 20 years due its enormous market potential [146].

In oral administration, hydrogels can deliver drugs to four major specific sites: mouth, stomach, small intestine and colon. By controlling their swelling properties or mucoadhesive characteristics in the presence of a biological fluid, hydrogels can be a useful carrier to release drugs in a controlled manner at these desired sites. Furthermore, the mucoadhesive hydrogels offer an attractive property for drug targeting at certain specific regions, leading to a locally increased drug concentration and, consequently, enhancing the drug absorption at the release site [20,50].

The application of mucoadhesive hydrogels in buccal drug delivery seems to have some advantages like a rapid drug action, the absence of hepatic first-pass metabolism and the absence of drug degradation in the gastrointestinal tract due the low $\mathrm{pH}$ values $[147,148]$. For maximum benefit from drug delivery buccal bioadhesive hydrogels were developed. They can be prepared using different polymers namely hydroxyethylcellulose (HEC), hydroxypropylcellulose (HPC), polyvinylpyrrolidone (PVP), and poly(vinyl alcohol) [149], or mixtures of different polymers, such as HPC, hydroxypropylmethylcellulose (HPMC), karaya gum and polyethylene glycol (PEG) 400 [146], or HPC and Carbopol 934 [150].

\subsection{Ocular Route}

The ocular route is mainly used for the local treatment of eye pathologies. Many physiological constraints prevent a desired drug delivery to the eye due to its protective mechanisms, such as effective tear drainage, blinking and low permeability of the cornea. Therefore, conventional eyedrops containing a drug solution tend to be eliminated rapidly from the eye, and drugs administered exhibit limited absorption, leading to poor ophthalmic bioavailability (2\% - 10\%). Additionally, their short retention time in the local of action often results in a frequent dosing regimen to achieve the therapeutic efficacy for a sufficiently long duration. These challenges have motivated researchers to develop drug delivery systems to provide a prolonged ocular residence time of drugs [151].

The following types of mucoadhesive formulations have been evaluated for ocular drug delivery: viscous liquids (suspensions and ointments), hydrogels and, solids (inserts). Certain dosage forms, such as suspensions and ointments, can be retained in the eye, although these formulations sometimes give to the patients an unpleasant feeling because of the solid and semi-solid characteristics. Due to their elastic properties, hydrogels can also represent an ocular drainage-resistant device. In particular, in-situ hydrogels are attractive as an ocular drug delivery system because of their facility in dosing as a liquid and, their long-term retention property as a gel after dosing. Hui and Robinson [152] introduced hydrogels consisting of cross-linked PAA for ocular delivery of progesterone in rabbits. These preparations increased progesterone concentration in the aqueous humor four times over aqueous suspensions. Cohen and collaborators [153] developed an in situ gel system of alginate with high guluronic acid content for ophthalmic delivery of pilocarpine. This system significantly extended the duration of the pressure-reducing effect of pilocarpine. Carlfors [154] investigated the rheological properties of the deacetylated gellan gum. These gels upon instillation in the eye due to the presence of cations and, the high rate of the sol/gel transition results in a long precorneal contact time. An approach for ocular inserts was presented by Chetoni and collaborators [155]. In this study, cylindrical devices for oxytetracycline were developed using mixtures of silicone clastomer and grafted on the surface of the inserts with an interpenetrating mucoadhesive polymeric network of PAA or PMAA. The ocular retention of IPN-grafted inserts was significantly higher than the ungrafted ones. An in vivo study using rabbits showed a prolonged release of oxytetracycline from the inserts for several days.

\subsection{Nasal Route}

The nasal route of drug administration is the most suitable alternative of drug delivery for poorly absorbable compounds such as peptide and proteins. The nasal epithelium exhibits relatively high permeability and, only two cell layers separate the nasal lumen from the dense blood-vessel network in the lamina propria. The respiretory epithelium covered by a mucus layer is the major lining of the human nasal cavity and is essential in the clearance of mucus by the mucociliary system [156].

Several structural mucoadhesive polymers were tested for their ability to retard the nasal mucociliary clearance in rats [157]. The clearance was measured using microspheres labeled with a fluorescent marker incorporated into the formulation. The clearance rate of each polymer gel was found to be lower than the control microsphere suspension, resulting in an increased residence time of the gel formulations in the nasal cavity. Ilium and collaborators [158] evaluated chitosan solutions as delivery platforms for nasal administration of insulin to rats and sheep. They reported a concentration-dependent absorption-enhancing effect with minimal histological changes 
of the nasal mucosa. Nakamura and collaborators [159] described a microparticulated dosage form of budesonide, consisting of bioadhesive and $\mathrm{pH}$-dependent graft copolymers of PMAA and PEG, resulting in an increase and constant plasma levels of budesonide for $8 \mathrm{~h}$ after nasal administration in rabbits.

\subsection{Transdermal Route}

The transdermal route has been considered as a possible site for the systemic delivery of drugs. The benefits of transdermal drug delivery systems include ease of application and delivery, sustained and steady drug release, reduced systemic side effects, avoidance of drug degradation in the GI tract and first-pass hepatic metabolism. Furthermore, swollen hydrogels with high water content can provide a better feeling for the skin compared with conventional ointments and patches. Versatile hydrogelbased devices for transdermal delivery have been proposed. Sun and collaborators [160] prepared composite membranes comprising of cross-linked poly (hydroxyethylmethacrylate) (PHEMA) with a non-woven polyester support. Depending on the preparation conditions, the composite membranes could be tailored to give a permeation flux ranging from 4 to $68 \mathrm{mg} / \mathrm{cm}^{2}$ per h for nitroglycerin. Gayet and Fortier [161] reported the use of the (bovine serum albumin) BSA-PEG hydrogels containing high water content over $96 \%$ as controlled release devices in the field of wound dressing. However, skin acts as a barrier to foreign substances, preventing the entrance of the majority of drugs. Therefore, researchers have been developed several electrically assisted methods to enhance the drug permeation across the skin, including electroporation, ionophoresis, sonophoresis and, laser irradiation [162-164].

\section{Conclusions and Future Trends}

Actually, there are enough scientific evidences for the potentiality of hydrogels in the delivery of drug molecules to a desired site by triggering the release through an external stimulus such as temperature, $\mathrm{pH}$, glucose or light. These systems being biocompatible and biodegradable in nature have been used in the development of nanobiotechnological products and have excellent applications in the field of controlled drug delivery as well. This is the reason because these turn-able biomedical devices are gaining attention as intelligent drug carrier systems.

In fact, the design and synthesis of environment-sensitive hydrogels has significant potential in future biomedical and nanotechnology applications. The success of these materials relies on the development of novel materials that can address specific biological and medical challenges. This development will occur through the syn- thesis of new polymers or by modification of natural polymers. Hydrogels being used for cartilage or tissue engineering should be capable to providing mechanical properties as well as the molecular signals that are present in the native or regenerative organ. Finally, advanceing the knowledge and the use of hydrogels and sensitive polymers for nanotechnology is an important area with significant potential that remains to be fully investigation.

Finally, it is possible to conclude that many significant recent advances in biomaterials occur at the interface of clinical medicine, materials science and engineering. This aspect creates opportunities and training programs for individual cross-disciplinary research and the engaged in these areas can significant accelerate the advance of biomaterials and create new applications for these materials in medicine.

\section{Acknowledgements}

This work was financially supported by a Grant (Praxis SFRH/BD/48324/2008) from FCT (Fundação para a Ciência e a Tecnologia, Portugal).

\section{REFERENCES}

[1] S. M. Gomes, H. Azevedo, P. Malafaya, S. Silva, J. Oliveira, G. Silva, R. Sousa, J. Mano and R. Reis, "Natural Polymers in Tissue Engineering Applications,” In: C. V. Blitterswijk, Ed., Tissue Engineering, Academic Press, Waltham, 2008, pp. 146-191.

[2] B. D. Ratner and A. S. Hoffman, "Hydrogels for Medical and Related Applications,” ACS Publications, Washington DC, 1976.

[3] N. A. Peppas, "Hydrogels in Medicine and Pharmacy," CRC Press, Boca Raton, 1986.

[4] N. A. Peppas and R. Langer, "New Challenges in Biomaterials,” Science, Vol. 263, No. 5154, 1994, pp. 17151720. doi:10.1126/science.8134835

[5] A. S. Hoffman, "Hydrogels for Biomedical Applications," Advanced Drug Delivery Reviews, Vol. 54, No. 1, 2002, pp. 3-12. doi:10.1016/S0169-409X(01)00239-3

[6] J. Jagur-Grodzinski, "Polymeric Gels and Hydrogels for Biomedical and Pharmaceutical Applications," Polymers for Advanced Technologies, Vol. 21, No. 1, 2009, pp. 2747. doi:10.1002/pat.1504

[7] B. K. Nanjawade, F. V. Manvi and A.S. Manjappa, “In Situ-Forming Hydrogels for Sustained Ophthalmic Drug Delivery,” Journal of Controlled Release, Vol. 122, No. 2, 2007, pp. 119-134. doi:10.1016/j.jconrel.2007.07.009

[8] L. Xinming, C. Yingde, A. W. Lloyd, S. V. Mikhalovsky, S. R. Sandeman, C. A. Howel and L. Liewen, "Polymeric Hydrogels for Novel Contact Lens-Based Ophthalmic Drug Delivery Systems: A Review," Contact Lens \& Anterior Eye, Vol. 31, No. 2, 2008, pp. 57-64. doi:10.1016/j.clae.2007.09.002

[9] S. Brahim, D. Narinesingh and A. Guiseppi-Elie, "Polypyr- 
role-Hydrogel Composites for the Construction of Clinically Important Biosensors,” Biosensors and Bioelectronics, Vol. 17, No. 1-2, 2002, pp. 53-59. doi:10.1016/S0956-5663(01)00262-7

[10] N. B. Graham and M. E. McNeill, "Hydrogels for Controlled Drug Delivery,” Biomaterials, Vol. 5, No. 1, 1984, pp. 27-36. doi:10.1016/0142-9612(84)90063-2

[11] N. A. Peppas, Y. Huang, M. Torres-Lugo, J. H. Ward and J. Zhang, "Physicochemical, Foundations and Structural Design of Hydrogels in Medicine and Biology," Annual Review of Biomedical Engineering, Vol. 2, 2000, pp. 9-29. doi:10.1146/annurev.bioeng.2.1.9

[12] L. Chen, Z. Tian and Y. Du, "Synthesis and pH Sensitivity of Carboxymethyl Chitosan-Based Polyampholyte Hydrogels for Protein Carrier Matrices,” Biomaterials, Vol. 25, No. 17, 2004, pp. 3725-3732. doi:10.1016/j.biomaterials.2003.09.100

[13] Q. Li, J. Wang, S. Shahani, D. D. N. Sun, B. Sharma, J. H. Elisseeff and K. W. Leong, "Biodegradable and Photocrosslinkable Polyphosphoester Hydrogel,” Biomaterials, Vol. 27, No. 17, 2006, pp. 1027-1034. doi:10.1016/j.biomaterials.2005.07.019

[14] T. R. Hoare and D. S. Kohane, "Hydrogels in Drug Delivery: Progress and Challenges,” Polymer, Vol. 49, No. 8, 2008, pp. 1993-2007. doi:10.1016/j.polymer.2008.01.027

[15] R. Langer and J. P. Vacanti, “Tissue Engineering,” Science, Vol. 260, No. 5110, 1993, pp. 920-926. doi:10.1126/science.8493529

[16] J. L. Drury and D. J. Mooney, "Hydrogels for Tissue Engineering: Scaffold Design Variables and Applications," Biomaterials, Vol. 24, No. 24, 2003, pp. 43374351. doi:10.1016/S0142-9612(03)00340-5

[17] K. A. Davis and K. S. Anseth, "Controlled Release from Crosslinked Degradable Networks," Critical Reviews in Therapeutic Drug Carrier Systems, Vol. 19, No. 4-5, 2002, pp. 385-423. doi:10.1615/CritRevTherDrugCarrierSyst.v19.i45

[18] K. Y. Lee and S. H. Yuk, "Polymeric Protein Delivery Systems," Progress in Polymer Science, Vol. 32, No. 7, 2007, pp. 669-697. doi:10.1016/j.progpolymsci.2007.04.001

[19] T. Coviello, P. Matricardi, C. Marianecci and F. Alhaique, "Polysaccharide Hydrogels for Modified Release Formulations," Journal of Controlled Release, Vol. 119, No. 1, 2007, pp. 5-24. doi:10.1016/j.jconrel.2007.01.004

[20] S. H. Jeong, K. M. Huh and K. Park, "Hydrogel Drug Delivery Systems, in Polymers in Drug Delivery," CRC press, Boca Raton, 2006.

[21] K. R. Kamath and K. Park, "Biodegradable Hydrogels in Drug Delivery,” Advanced Drug Delivery Reviews, Vol. 11, No. 1-2, 1993, pp. 59-84. doi:10.1016/0169-409X(93)90027-2

[22] P. M. de la Torre, S. Torrado and S. Torrado, "Interpolymer Complexes of Poly(Acrylic Acid) and Chitosan: Influence of the Ionic Hydrogel-Forming Medium," Biomaterials, Vol. 24, No. 8, 2003, pp. 1459-1468. doi:10.1016/S0142-9612(02)00541-0

[23] Y. Kumashiro, K. M. Huh, T. Ooya and N. Yui, "Modu- latory Factors on Temperature-Synchronized Degradation of Dextran Grafted with Thermoresponsive Polymers and Their Hydrogels,” Biomacromolecules, Vol. 2, No. 3, 2001, pp. 874-879. doi:10.1021/bm015527y

[24] J. Kopecek and J. Yang, "Hydrogels as Smart Biomaterials,” Polymer International, Vol. 56, No. 9, 2007, pp. 1078-1098. doi:10.1002/pi.2253

[25] S. A. Lapidot, J. Kost, K. H. J. Buschow, W. C. Robert, C. F. Merton, I. Bernard, J. K. Edward, M. Subhash and V. Patrick, "Hydrogels," In: K. H. J. Buschow, et al., Eds., Encyclopedia of Materials: Science and Technology, Elsevier, Oxford, 2001, pp. 3878- 3882.

[26] T. Tamar, K. Joseph and A. L. Smadar, "Modeling Ionic Hydrogels Swelling: Characterization of the Non-Steady State,” Biotechnology and Bioengineering, Vol. 84, No. 1, 2003, pp. 20-28. doi:10.1002/bit.10736

[27] T. Traitel, Y. Cohen and J. Kost, "Characterization of Glucose-Sensitive Insulin Release Systems in Simulated in Vivo Conditions,” Biomaterials, Vol. 21, No. 16, 2000, pp. 1679-1687. doi:10.1016/S0142-9612(00)00050-8

[28] K. Wang, J. Burban and E. Cussler, "Hydrogels as Separation Agents,” Responsive Gels: Volume Transitions II, Vol. 110, 1993, pp. 67-79. doi:10.1007/BFb0021129

[29] L. Brannon-Peppas and N. A. Peppas, "Dynamic and Equilibrium Swelling Behaviour of $\mathrm{pH}$-Sensitive Hydrogels Containing 2-Hydroxyethyl Methacrylate,” Biomaterials, Vol. 11, No. 9, 1990, pp. 635-644. doi:10.1016/0142-9612(90)90021-H

[30] C. Jun, P. Haesun and P. Kinam, "Synthesis of Superporous Hydrogels: Hydrogels with Fast Swelling and Superabsorbent Properties,” Journal of Biomedical Materials Research A, Vol. 44, No. 1, 1999, pp. 53-62. doi:10.1002/(SICI)1097-4636(199901)44:1<53::AID-JB M6>3.0.CO;2-W

[31] P. Kofinas and R. E. Cohen, "Development of Methods for Quantitative Characterization of Network Morphology in Pharmaceutical Hydrogels,” Biomaterials, Vol. 18, No. 20, 1997, pp. 1361-1369. doi:10.1016/S0142-9612(97)00077-X

[32] K. Pathmanathan and G. P. Johari, "Relaxation and Crystallization of Water in a Hydrogel," Journal of Chemical Society Faraday Transactions, Vol. 90, No. 8, 1994, pp. 1143-1148. doi:10.1039/FT9949001143

[33] H. Park, K. Park and W. S. W. Shalaby, "Biodegradable Hydrogels for Drug Delivery,” CRC Press, Boca Raton, 1993.

[34] A. M. Lowman and N. A. Peppas, "Analysis of the Complexation/Decomplexation Phenomena in Graft Copolymer Networks,” Macromolecules, Vol. 30, No.17, 1997, pp. 4959-4965. doi:10.1021/ma970399k

[35] B. Jeong, Y.K. Choi, Y. H. Bae, G. Zentner and S. W. Kim, "New Biodegradable Polymers for Injectable Drug Delivery Systems,” Journal of Controlled Release, Vol. 62, No, 1-2, 1999, pp. 109-114. doi:10.1016/S0168-3659(99)00061-9

[36] N. A. Peppas, "Physiologically Responsive Hydrogels," Journal of Bioactive and Compatible Polymers, Vol. 6, No. 3, 1991, pp. 241-246. 


\section{doi:10.1177/088391159100600303}

[37] A. R. Khare and N. A. Peppas, "Swelling/Deswelling of Anionic Copolymer Gels,” Biomaterials, Vol. 16, No. 7, 1995, pp. 559-567. doi:10.1016/0142-9612(95)91130-Q

[38] N. A. Peppas, A. R. Khare, "Preparation, Structure and Diffusional Behavior of Hydrogels in Controlled Release," Advanced Drug Delivery Reviews, Vol. 11, No. 12, 1993, pp. 1-35. doi:10.1016/0169-409X(93)90025-Y

[39] S. Amin, S. Rajabnezhad and K. Kohli, "Hydrogels as Potential Drug Delivery Systems," Scientific Research and Essays, Vol. 4, No. 11, 2009, pp. 1175-1183.

[40] C. C. Lin and A. T. Metters, "Hydrogels in Controlled Release Formulations: Network Design and Mathematical Modeling," Advanced Drug Delivery Reviews, Vol. 58, No. 12-13, 2006, pp. 1379-1408. doi:10.1016/j.addr.2006.09.004

[41] W. E. Hennink and C. F. van Nostrum, "Novel Crosslinking Methods to Design Hydrogels," Advanced Drug Delivery Reviews, Vol. 54, No. 1, 2002, pp. 13-36. doi:10.1016/S0169-409X(01)00240-X

[42] A. M. Lowman and N. A. Peppas, "Encyclopedia of Controlled Drug Delivery,” John Wiley \& Sons, Hoboken, 1999.

[43] S. W. Kim, Y. H. Bae, "Stimuli-Modulated Delivery Systems,” In: G. L.Amidon, P. I. Lee and E. M. Topp, Eds., Transport Processes in Pharmaceutical Systems, Marcel Dekker, New York, 2000, pp. 547-573.

[44] A. Gutowska, J. S. Bark, I. Chan Kwon, Y. Han Bae, Y. Cha and S. Wan Kim, "Squeezing Hydrogels for Controlled Oral Drug Delivery," Journal of Controlled Release, Vol. 48, No. 2-3, 1997, pp. 141-148. doi:10.1016/S0168-3659(97)00041-2

[45] I. Y. Galaev, "Smart Polymers in Biotechnology and Medicine,” Russian Chemical Reviews, Vol. 64, No. 5, 1995, pp. 471-489. doi:10.1070/RC1995v064n05ABEH000161

[46] I. Y. Galaev and B. Mattiasson, "Smart' Polymers and What They Could Do in Biotechnology and Medicine," Trends in Biotechnology, Vol. 17, No. 8, 1999, pp. 335340. doi:10.1016/S0167-7799(99)01345-1

[47] P. S. Stayton, M. E. H. El-Sayed, N. Murthy, V. Bulmus, C. Lackey, C. Cheung and A. S. Hoffman, "Smart Delivery Systems for Biomolecular Therapeutics,” Orthodontics and Craniofacial Research, Vol. 8, No. 3, 2005, pp. 219-225. doi:10.1111/j.1601-6343.2005.00336.x

[48] Y. Qiu and K. Park, "Environment-Sensitive Hydrogels for Drug Delivery,” Advanced Drug Delivery Reviews, Vol. 53, No. 3, 2001, pp. 321-339. doi:10.1016/S0169-409X(01)00203-4

[49] J. C. Ruiz, C. Alvarez-Lorenzo, P. Taboada, G. Burillo, E. Bucio, K. de Prijck, H. J. Nelis, T. Coenye and A. Concheiro, "Polypropylene Grafted with Smart Polymers (PNIPAAm/PAAc) for Loading and Controlled Release of Vancomycin," European Journal of Pharmaceutics and Biopharmaceutics, Vol. 70, No. 2, 2008, pp. 467-477. doi:10.1016/j.ejpb.2008.05.020

[50] N. A. Peppas, P. Bures, W. Leobandung and H. Ichikawa, "Hydrogels in Pharmaceutical Formulations," European
Journal of Pharmaceutics and Biopharmaceutics, Vol. 50, No. 1, 2000, pp. 27-46. doi:10.1016/S0939-6411(00)00090-4

[51] B. Erman and P. J. Flory, "Critical Phenomena and Transitions in Swollen Polymer Networks and in Linear Macromolecules," Macromolecules, Vol. 19, No. 9, 1986, pp. 2342-2353. doi:10.1021/ma00163a003

[52] J. Ma, X. Liu, Z. Yang and Z. Tong, “A pH-Sensitive Hydrogel with Hydrophobic Association for Controlled Release of Poorly Water-Soluble Drugs,” Journal of Macromolecular Science: Pure and Applied Chemistry, Vol. 46, No. 8, 2009, pp. 816-820. doi:10.1080/10601320903004707

[53] C. H. Alarcon, S. Pennadam and C. Alexander, "Stimuli Responsive Polymers for Biomedical Applications," Chemical Society Reviews, Vol. 34, No. 3, 2005, pp. 276 285. doi:10.1039/B406727D

[54] A. S. Hoffman and P. S. Stayton, "Conjugates of StimuliResponsive Polymers and Proteins," Progress in Polymer Science, Vol. 32, No. 8-9, 2007, pp. 922-932. doi:10.1016/j.progpolymsci.2007.05.005

[55] R. J. Mart, R. D. Osborne, M. M. Stevens and R. V. Ulijn, "Peptide-Based Stimuli-Responsive Biomaterials," Soft Matter, Vol. 2, No. 10, 2006, pp. 822-835. doi:10.1039/B607706D

[56] P. Ali and B. Shahram, "Synthesis and Evaluation of $\mathrm{pH}$ and Thermosensitive Pectin-Based Superabsorbent Hydrogel for Oral Drug Delivery Systems,” Starch-Stärke, Vol. 61, No. 3-4, 2009, pp. 161-172. doi:10.1002/star.200800063

[57] J. Chen and K. Park, "Synthesis and Characterization of Superporous Hydrogel Composites,” Journal of Controlled Release, Vol. 65, No. 1-2, 2000, pp. 73-82. doi:10.1016/S0168-3659(99)00238-2

[58] J. Zhang, K. Yuan, Y. P. Wang, S. J. Gu and S. T. Zhang, "Preparation and Properties of Polyacrylate/Bentonite Superabsorbent Hybrid via Intercalated Polymerization," Materials Letters, Vol. 61, No. 2, 2007, pp. 316-320. doi:10.1016/j.matlet.2006.04.055

[59] B. G. Geest, C. Déjugnat, G. B. Sukhorukov, K. Braeckmans, S. C. De Smedt and J. Demeester, "Self-Rupturing Microcapsules,” Advanced Materials, Vol. 17, No. 19, 2005, pp. 2357-2361. doi:10.1002/adma.200401951

[60] D. Yonghui, W. Changchun, S. Xizhong, Y. Wuli, J. Lan, G. Hong and F. Shoukuan, "Preparation, Characterization, and Application of Multistimuli-Responsive Microspheres with Fluorescence-Labeled Magnetic Cores and Thermoresponsive Shells," Chemistry European Journal, Vol. 11, No. 20, 2005, pp. 6006-6013. doi:10.1002/chem.200500605

[61] J. D. Ehrick, S. K. Deo, T. W. Browning, L. G. Bachas, M. J. Madou and S. Daunert, "Genetically Engineered Protein in Hydrogels Tailors Stimuli-Responsive Characteristics,” Nature Materials, Vol. 4, No. 4, 2005, pp. 298302.

[62] J. Gu, F. Xia, Y. Wu, X. Qu, Z. Yang and L. Jiang, "Programmable Delivery of Hydrophilic Drug Using Dually Responsive Hydrogel Cages,” Journal of Controlled Release, Vol. 117, No. 3, 2007, pp. 396-402. 
doi:10.1016/j.jconrel.2006.11.029

[63] K. S. V. K. Rao, B. V. K. Naidu, M. C. S. Subha, M. Sairam and T. M. Aminabhavi, "Novel Chitosan-Based pH-Sensitive Interpenetrating Network Microgels for the Controlled Release of Cefadroxil," Carbohydrate Polymers, Vol. 66, No. 3, 2006, pp. 333-344.

doi:10.1016/j.carbpol.2006.03.025

[64] K. S. Soppimath, A. R. Kulkarni and T. M. Aminabhavi, "Chemically Modified Polyacrylamide-g-Guar Gum-Based Crosslinked Anionic Microgels as pH-Sensitive Drug Delivery Systems: Preparation and Characterization,” Journal of Controlled Release, Vol. 75, No. 3, 2001, pp. 331345. doi:10.1016/S0168-3659(01)00404-7

[65] G. Tae, M. Scatena, P. S. Stayton and A. S. Hoffman, "PEG-Cross-Linked Heparin Is an Affinity Hydrogel for Sustained Release of Vascular Endothelial Growth Factor," Journal of Biomaterials Science Polymer Edition, Vol. 17, No. 1-2, 2006, pp. 187-197. doi:10.1163/156856206774879090

[66] P. D. Thornton, R. J. Mart and R. V. Ulijn, "EnzymeResponsive Polymer Hydrogel Particles for Controlled Release,” Advanced Materials, Vol. 19, No. 9, 2007, pp. 1252-1256. doi:10.1002/adma.200601784

[67] I. R. Wheeldon, S. Calabrese Barton and S. Banta, "Bioactive Proteinaceous Hydrogels from Designed Bifunctional Building Blocks,” Biomacromolecules, Vol. 8, No. 10, 2007, pp. 2990-2994. doi:10.1021/bm700858p

[68] K. C. Wood, H. F. Chuang, R. D. Batten, D. M. Lynn and P. T. Hammond, "Controlling Interlayer Diffusion to Achieve Sustained, Multiagent Delivery from Layer-ByLayer Thin Films," Proceedings of the National Academy of Sciences, Vol. 103, No. 27, 2006, pp. 10207-10212. doi:10.1073/pnas.0602884103

[69] J. Zhou, G. Wang, L. Zou, L. Tang, M. Marquez and Z. $\mathrm{Hu}$, "Viscoelastic Behavior and in Vivo Release Study of Microgel Dispersions with Inverse Thermoreversible Gelation," Biomacromolecules, Vol. 9, No. 1, 2008, pp. 142148. doi:10.1021/bm700918d

[70] N. Singh, A. W. Bridges, A. J. Garcia and L. A. Lyon, "Covalent Tethering of Functional Microgel Films onto Poly(Ethylene Terephthalate) Surfaces,” Biomacromolecules, Vol. 8, No. 10, 2007, pp. 3271-3275. doi:10.1021/bm700516v

[71] C. M. Nolan, C. D. Reyes, J. D. Debord, A. J. Garcia and L. A. Lyon, "Phase Transition Behavior, Protein Adsorption, and Cell Adhesion Resistance of Poly(Ethylene Glycol) Cross-Linked Microgel Particles,” Biomacromolecules, Vol. 6, No. 4, 2005, pp. 2032-2039. doi:10.1021/bm0500087

[72] D. Gan and L. A. Lyon, "Synthesis and Protein Adsorption Resistance of PEG-Modified Poly(N-Isopropylacrylamide) Core/Shell Microgels,” Macromolecules, Vol. 35, No. 26, 2002, pp. 9634-9639. doi:10.1021/ma021186k

[73] P. Kim, D. Kim, B. Kim, S. Choi, S. Lee, A. Khademhosseini, R. Langer and K. Y. Suh, "Fabrication of Nanostructures of Polyethylene Glycol for Applications to Protein Adsorption and Cell Adhesion," Nanotechnology, Vol. 16, No. 10, 2005, pp. 2420-2426. doi:10.1088/0957-4484/16/10/072

[74] H. Cong, A. Revzin and T. Pan, "Non-Adhesive PEG Hydrogel Nanostructures for Self-Assembly of Highly Ordered Colloids,” Nanotechnology, Vol. 20, 2009, Article ID: 075307. doi:10.1088/0957-4484/20/7/075307

[75] K. S. Jeong, P. S. Jun, L. S. Min, L. Y. Moo, K. H. Chan and I. K. Sun, "Electroactive Characteristics of Interpenetrating Polymer Network Hydrogels Composed of Poly(Vinyl Alcohol) and Poly(N-Isopropylacrylamide)," Journal of Applied Polymer Science, Vol. 89, No. 4, 2003, pp. 890-894. doi:10.1002/app.12331

[76] J. Raula, J. Shan, M. Nuopponen, A. Niskanen, H. Jiang, E. I. Kauppinen and H. Tenhu, "Synthesis of Gold Nanoparticles Grafted with a Thermoresponsive Polymer by Surface-Induced Reversible-Addition-Fragmentation ChainTransfer Polymerization,” Langmuir, Vol. 19, No. 8, 2003, pp. 3499-3504. doi:10.1021/la026872r

[77] M. Yamato, M. Utsumi, A. Kushida, C. Konno, A. Kikuchi and T. Okano, "Thermo-Responsive Culture Dishes Allow the Intact Harvest of Multilayered Keratinocyte Sheets without Dispase by Reducing Temperature," Tissue Engineering, Vol. 7, No. 4, 2001, pp. 473-480. doi:10.1089/10763270152436517

[78] K. S. Anseth, A. T. Metters, S. J. Bryant, P. J. Martens, J. H. Elisseeff, C. N. Bowman, "In Situ Forming Degradable Networks and Their Application in Tissue Engineering and Drug Delivery," Journal of Controlled Release, Vol. 78, No. 1-3, 2002, pp. 199-209. doi:10.1016/S0168-3659(01)00500-4

[79] C. Chung and J. A. Burdick, "Engineering Cartilage Tissue,” Advanced Drug Delivery Reviews, Vol. 60, No. 2, 2008, pp. 243-262. doi:10.1016/j.addr.2007.08.027

[80] D. Y. Fozdar, W. Zhang, M. Palard, C. W. Patrick Jr. and S. Chen, "Flash Imprint Lithography Using a Mask Aligner: A Method for Printing Nanostructures in Photosensitive Hydrogels," Nanotechnology, Vol. 19, No. 21, 2008, pp. 215-303. doi:10.1088/0957-4484/19/21/215303

[81] K. Y. Suh, M. C. Park and P. Kim, "Capillary Force Lithography: A Versatile Tool for Structured Biomaterials Interface towards Cell and Tissue Engineering”, $A d$ vanced Functional Materials, Vol. 19, No. 17, 2009, pp. 2699-2712. doi:10.1002/adfm.200900771

[82] M. P. Lutolf and J. A. Hubbell, "Synthetic Biomaterials as Instructive Extracellular Microenvironments for Morphogenesis in Tissue Engineering," Nature Biotechnology, Vol. 23, No. 1, 2005, pp. 47-55.

[83] B. K. Mann, “Biologic Gels in Tissue Engineering,” Clinics in Plastic Surgery, Vol. 30, No. 4, 2003, pp. 601-609. doi:10.1016/S0094-1298(03)00078-6

[84] C. Schwall and I. Banerjee, "Micro- and Nanoscale Hydrogel Systems for Drug Delivery and Tissue Engineering,” Materials, Vol. 2, No. 2, 2009, pp. 577-612. doi:10.3390/ma2020577

[85] M. Sokolsky-Papkov, K. Agashi, A. Olaye, K. Shakesheff and A. J. Domb, "Polymer Carriers for Drug Delivery in Tissue Engineering," Advanced Drug Delivery Reviews, Vol. 59, No. 4-5, 2007, pp. 187-206. doi:10.1016/j.addr.2007.04.001

[86] H. J. Wang, L. Di, Q. S. Ren and J. Y. Wang, “Applica- 
tions and Degradation of Proteins Used as Tissue Engineering Materials,” Materials, Vol. 2, No. 2, 2009, pp. 613-635. doi:10.3390/ma2020613

[87] C. Weinand, I. Pomerantseva, C. M. Neville, R. Gupta, E. Weinberg, I. Madisch, F. Shapiro, H. Abukawa, M. J. Troulis and J. P. Vacanti, "Hydrogel- $\beta$-TCP Scaffolds and Stem Cells for Tissue Engineering Bone,” Bone, Vol. 38, No. 4, 2006, pp. 555-563. doi:10.1016/j.bone.2005.10.016

[88] S. X. Zheng, A. Shama, L. Yanchun and D. P. Glenn, "Synthesis and Evaluation of Injectable, in Situ Crosslinkable Synthetic Extracellular Matrices for Tissue Engineering," Journal of Biomedical Materials Research A, Vol. 79A, No. 4, 2006, pp. 902-912. doi:10.1002/jbm.a.30831

[89] X. Q. Jia and L. K. Kristi, "Hybrid Multicomponent Hydrogels for Tissue Engineering," Macromolecular Bioscience, Vol. 9, No. 2, 2009, pp. 140-156. doi:10.1002/mabi.200800284

[90] L. Serra, J. Doménech and N. A. Peppas, "Engineering Design and Molecular Dynamics of Mucoadhesive Drug Delivery Systems as Targeting Agents," European Journal of Pharmaceutics and Biopharmaceutics, Vol. 71, No. 3, 2009, pp. 519-528. doi:10.1016/j.ejpb.2008.09.022

[91] G. P. Andrews, T. P. Laverty and D. S. Jones, "Mucoadhesive Polymeric Platforms for Controlled Drug Delivery," European Journal of Pharmaceutics and Biopharmaceutics, Vol. 71, No. 3, 2009, pp. 505-518. doi:10.1016/j.ejpb.2008.09.028

[92] N. A. Peppas and J. J. Sahlin, "Hydrogels as Mucoadhesive and Bioadhesive Materials: A Review," Biomaterials, Vol. 17, No. 16, 1996, pp. 1553-1561. doi:10.1016/0142-9612(95)00307-X

[93] Y. H. Bae, T. Okano and S. W. Kim, “'On-Off' Thermocontrol of Solute Transport. I. Temperature Dependence of Swelling of N-Isopropylacrylamide Networks Modified with Hydrophobic Components in Water," Pharmaceutical Research, Vol. 8, No. 4, 1991, pp. 531-537. doi:10.1023/A:1015871732706

[94] Y. H. Bae, T. Okano and S. W. Kirn, “'On-Off' Thermocontrol of Solute Transport. II. Solute Release from Thermosensitive Hydrogels," Pharmaceutical Research, Vol. 8, No. 5, 1991, pp. 624-628. doi:10.1023/A:1015860824953

[95] B. Jeong, S. W. Kim and Y. H. Bae, "Thermosensitive Sol-Gel Reversible Hydrogels,” Advanced Drug Delivery Reviews, Vol. 54, No. 1, 2002, pp. 37-51. doi:10.1016/S0169-409X(01)00242-3

[96] E. Ruel-Gariépy and J. C. Leroux, "In Situ-Forming Hydrogels-Review of Temperature-Sensitive Systems," European Journal of Pharmaceutics and Biopharmaceutics, Vol. 58, No. 2, 2004, pp. 409-426. doi:10.1016/j.ejpb.2004.03.019

[97] X. Zhang and R. Zhuo, "Synthesis of Temperature-Sensitive Poly(N-Isopropylacrylamide) Hydrogel with Improved Surface Property," Journal of Colloid and Interface Science, Vol. 223, No. 2, 2000, pp. 311-313. doi:10.1006/jcis.1999.6654

[98] C. Alvarez-Lorenzo, A. Concheiro, A. S. Dubovik, N. V.
Grinberg, T. V. Burova and V. Y. Grinberg, “Temperature-Sensitive Chitosan-Poly(N-Isopropylacrylamide) InTerpenetrated Networks with Enhanced Loading Capacity and Controlled Release Properties,” Journal of Controlled Release, Vol. 102, No. 3, 2005, pp. 629-641. doi:10.1016/j.jconrel.2004.10.021

[99] M. Yamato, Y. Akiyama, J. Kobayashi, J. Yang, A. Kikuchi and T. Okano, "Temperature-Responsive Cell Culture Surfaces for Regenerative Medicine with Cell Sheet Engineering," Progress in Polymer Science, Vol. 32, No. 8-9, 2007, pp. 1123-1133. doi:10.1016/j.progpolymsci.2007.06.002

[100] L. Pérez-Alvarez, V. S. Martínez, E. Hernáez and I. Katime, "Novel pH- and Temperature-Responsive Methacrylamide Microgels," Macromolecular Chemistry and Physics, Vol. 210, No. 13-14, 2009, pp. 1120-1126. doi:10.1002/macp.200900058

[101] I. C. Kwon, Y. H. Bae, T. Okano and S. W. Kim, "Drug Release from Electric Current Sensitive Polymers," Journal of Controlled Release, Vol. 17, No. 2, 1991, pp. 149153. doi:10.1016/0168-3659(91)90054-H

[102] K. Sawahata, M. Hara, H. Yasunaga and Y. Osada, "Electrically Controlled Drug Delivery System Using Polyelectrolyte Gels,” Journal of Controlled Release, Vol. 14, No. 3, 1990, pp. 253-262. doi:10.1016/0168-3659(90)90165-P

[103] H. Li, R. Luo and K. Y. Lam, "Modeling of Ionic Transport in Electric-Stimulus-Responsive Hydrogels," Journal of Membrane Science, Vol. 289, No. 1-2, 2007, pp. 284296. doi:10.1016/j.memsci.2006.12.011

[104] H. Li, "Kinetics of Smart Hydrogels Responding to Electric Field: A Transient Deformation Analysis,” International Journal of Solids and Structures, Vol. 46, No. 6, 2009, pp. 1326-1333. doi:10.1016/j.ijsolstr.2008.11.001

[105] A. Mamada, T. Tanaka, D. Kungwatchakun and M. Irie, "Photoinduced Phase Transition of Gels," Macromolecules, Vol. 23, No. 5, 1990, pp. 1517-1519. doi:10.1021/ma00207a046

[106] F. M. Andreopoulos, E. J. Beckman and A. J. Russell, "Light-Induced Tailoring of PEG-Hydrogel Properties," Biomaterials, Vol. 19, No. 15, 1998, pp. 1343-1352. doi:10.1016/S0142-9612(97)00219-6

[107] C. Alvarez-Lorenzo, S. Deshmukh, L. Bromberg, T. A. Hatton, I. Sandez-Macho and A. Concheiro, "Temperature- and Light-Responsive Blends of Pluronic F127 and poly $(N, N$-Dimethylacrylamide-co-Methacryloyloxyazobe nzene)," Langmuir, Vol. 23, No. 23, 2007, pp. 1147511481. doi:10.1021/la7019654

[108] C. Alvarez-Lorenzo, L. Bromberg and A. Concheiro, "Light-Sensitive Intelligent Drug Delivery Systems," Photochemistry and Photobiology, Vol. 85, No. 4, 2009, pp. 848-860. doi:10.1111/j.1751-1097.2008.00530.X

[109] J. Kost, J. Wolfrum and R. Langer, "Magnetically Enhanced Insulin Release in Diabetic Rats,” Journal of Biomedical Materials Research A, Vol. 21, No. 12, 1987, pp. 1367-1373. doi:10.1002/jbm.820211202

[110] L. L. Lao and R. V. Ramanujan, "Magnetic and Hydrogel Composite Materials for Hyperthermia Applications," Journal of Materials Science: Materials in Medicine, Vol. 
15, No. 10, 2004, pp. 1061-1064. doi:10.1023/B:JMSM.0000046386.78633.e5

[111] K. L. Ang, S. Venkatraman and R.V. Ramanujan, “Magnetic PNIPA Hydrogels for Hyperthermia Applications in Cancer Therapy,” Materials Science and Engineering C, Vol. 27, No. 3, 2007, pp. 347-351. doi:10.1016/j.msec.2006.05.027

[112] R. Ramanujan, K. Ang and S. Venkatraman, "MagnetPNIPA Hydrogels for Bioengineering Applications,” Journal of Materials Science, Vol. 44, No. 5, 2009, pp. 13811387. doi:10.1007/s10853-006-1064-X

[113] N. S. Satarkar and J. Z. Hilt, "Magnetic Hydrogel Nanocomposites for Remote Controlled Pulsatile Drug Release," Journal of Controlled Release, Vol. 130, No. 3, 2008, pp. 246-251. doi:10.1016/j.jconrel.2008.06.008

[114] M. Namdeo, S. K. Bajpai and S. Kakkar, "Preparation of a Magnetic-Field-Sensitive Hydrogel and Preliminary Study of Its Drug Release Behavior," Journal of Biomaterials Science Polymer Edition, Vol. 20, No. 12, 2009, pp. 1747-1761. doi:10.1163/156856208X386372

[115] L. C. Sederel, L. Does, B. J. Euverman, A. Bantjes, C. Kluft and H. J. M. Kempen, "Hydrogels by Irradiation of a Synthetic Heparinoid Polyelectrolyte," Biomaterials, Vol. 4, No. 1, 1983, pp. 3-8. doi:10.1016/0142-9612(83)90061-3

[116] I. Lavon and J. Kost, "Mass Transport Enhancement by Ultrasound in Non-Degradable Polymeric Controlled Release Systems," Journal of Controlled Release, Vol. 54, No. 1, 1998, pp. 1-7. doi:10.1016/S0168-3659(97)00112-0

[117] M. H. Casimiro, J. P. Leal and M. H. Gil, "Characterisation of Gamma Irradiated Chitosan/pHEMA Membranes for Biomedical Purposes,” Nuclear Instruments and Methods in Physics Research B, Vol. 236, No. 1-4, 2005, pp. 482-487. doi:10.1016/j.nimb.2005.04.023

[118] H. Zhang, H. Xia, J. Wang and Y. Li, "High Intensity Focused Ultrasound-Responsive Release Behavior of PLA-b-PEG Copolymer Micelles,” Journal of Controlled Release, Vol. 139, No. 1, 2009, pp. 31-39. doi:10.1016/j.jconrel.2009.05.037

[119] J. Berger, M. Reist, J. M. Mayer, O. Felt, N. A. Peppas and R. Gurny, "Structure and Interactions in Covalently and Ionically Crosslinked Chitosan Hydrogels for Biomedical Applications," European Journal of Pharmaceutics and Biopharmaceutics, Vol. 57, No. 1, 2004, pp. 1934. doi:10.1016/S0939-6411(03)00161-9

[120] M. Karbarz, W. Hyka and Z. Stojek, "Swelling Ratio Driven Changes of Probe Concentration in $\mathrm{pH}$ - and Ionic Strength-Sensitive Poly(Acrylic Acid) Hydrogels," Electrochemistry Communications, Vol. 11, No. 6, 2009, pp. 1217-1220. doi:10.1016/j.elecom.2009.04.005

[121] H. Li and Y. K. Yew, "Simulation of Soft Smart Hydrogels Responsive to pH Stimulus: Ionic Strength Effect and Case Studies," Materials Science and Engineering C, Vol. 29, No. 7, 2009, pp. 2261-2269. doi:10.1016/j.msec.2009.05.011

[122] L. Brannon-Peppas and N. A. Peppas, "Equilibrium Swelling Behavior of pH-Sensitive Hydrogels," Chemical Engineering Science, Vol. 46, No. 3, 1991, pp. 715-722.
doi:10.1016/0009-2509(91)80177-Z

[123] E. O. Akala, P. Kopecková and J. Kopecek, "Novel pHSensitive Hydrogels with Adjustable Swelling Kinetics," Biomaterials, Vol. 19, No. 11-12, 1998, pp. 1037-1047. doi:10.1016/S0142-9612(98)00023-4

[124] M. Torres-Lugo, M. García, R. Record and N. A. Peppas, "pH-Sensitive Hydrogels as Gastrointestinal Tract Absorption Enhancers: Transport Mechanisms of Salmon Calcitonin and Other Model Molecules Using the Caco-2 Cell Model,” Biotechnology Progress, Vol. 18, No. 3, 2002, pp. 612-616. doi:10.1021/bp0101379

[125] A. Richter, G. Paschew, S. Klatt, J. Lienig, K.-F. Arndt and H. J. Adler, "Review on Hydrogel-Based pH Sensors and Microsensors,” Sensors, Vol. 8, No. 1, 2008, pp. 561581. doi:10.3390/s8010561

[126] H. He, X. Cao and L. J. Lee, "Design of a Novel Hydrogel-Based Intelligent System for Controlled Drug Release," Journal of Controlled Release, Vol. 95, No. 3, 2004, pp. 391-402. doi:10.1016/j.jconrel.2003.12.004

[127] J. M. Varghese, Y. A. Ismail, C. K. Lee, K. M. Shin, M. K. Shin, S. I. Kim, I. So and S. J. Kim, "Thermoresponsive Hydrogels Based on Poly(N-Isopropylacrylamide) /Chondroitin Sulfate," Sensors and Actuators B Chemical, Vol. 135, No. 1, 2008, pp. 336-341. doi:10.1016/j.snb.2008.09.001

[128] T. Miyata, T. Uragami and K. Nakamae, "BiomoleculeSensitive Hydrogels," Advanced Drug Delivery Reviews, Vol. 54, No. 1, 2002, pp. 79-98. doi:10.1016/S0169-409X(01)00241-1

[129] R. Zhang, M. Tang, A. Bowyer, R. Eisenthal and J. Hubble, "Synthesis and Characterization of a D-Glucose Sensitive Hydrogel Based on CM-Dextran and Concanavalin A," Reactive and Functional Polymers, Vol. 66, No. 7, 2006, pp. 757-767. doi:10.1016/j.reactfunctpolym.2005.11.003

[130] M. Goldraich and J. Kost, “Glucose-Sensitive Polymeric Matrices for Controlled Drug Delivery,” Clinical Materials, Vol. 13, No. 1-4, 1993, pp. 135-142. doi:10.1016/0267-6605(93)90100-L

[131] J. J. Kim and K. Park, "Modulated Insulin Delivery from Glucose-Sensitive Hydrogel Dosage Forms,” Journal of Controlled Release, Vol. 77, No. 1-2, 2001, pp. 39-47. doi:10.1016/S0168-3659(01)00447-3

[132] R. Luo and H. Li, "Simulation Analysis of Effect of Ionic Strength on Physiochemical and Mechanical Characteristics of Glucose-Sensitive Hydrogels," Journal of Electroanalytical Chemistry, Vol. 635, No. 2, 2009, pp. 83-92. doi:10.1016/j.jelechem.2009.08.009

[133] Y. J. Kim, S. Choi, J. J. Koh, M. Lee, K. S. Ko and S. W. Kim, "Controlled Release of Insulin from Injectable Biodegradable Triblock Copolymer,” Pharmaceutical Research, Vol. 18, No. 4, 2001, pp. 548-550. doi:10.1023/A:1011074915438

[134] T. Miyata, N. Asami and T. Uragami, “A reversibly Antigen-Responsive Hydrogel,” Nature, Vol. 399, No. 6738, 1999, pp. 766-769.

[135] I. Schöll, G. Boltz-Nitulescu and E. Jensen-Jarolim, "Review of Novel Particulate Antigen Delivery Systems with 
Special Focus on Treatment of Type I Allergy,” Journal of Controlled Release, Vol. 104, No. 1, 2005, pp. 1-27. doi:10.1016/j.jconrel.2004.12.020

[136] A. K. Bajpai, S. K. Shukla, S. Bhanu and S. Kankane, "Responsive Polymers in Controlled Drug Delivery," Progress in Polymer Science, Vol. 33, No. 11, 2008, pp. 1088-1118. doi:10.1016/j.progpolymsci.2008.07.005

[137] N. Kashyap, N. Kumar and M. N. V. Kumar, "Hydrogels for Pharmaceutical and Biomedical Applications," Critical Reviews in Therapeutic Drug Carrier Systems, Vol. 22, No. 2, 2005, pp. 107-150. doi:10.1615/CritRevTherDrugCarrierSyst.v22.i2.10

[138] A. Kikuchi and T. Okano, "Pulsatile Drug Release Control Using Hydrogels,” Advanced Drug Delivery Reviews, Vol. 54, No. 1, 2002, pp. 53-77. doi:10.1016/S0169-409X(01)00243-5

[139] R. R. Burnette, “Theory of Mass Transfer”, In: J. R. Robinson and V. H. L. Lee, Eds., Controlled Drug Delivery: Fundamentals and Applications, Marcel Dekker, New York, 1987, pp. 95-138.

[140] B. Amsden, "Solute Diffusion within Hydrogels. Mechannisms and Models," Macromolecules, Vol. 31, No. 23, 1998, pp. 8382-8395. doi:10.1021/ma980765f

[141] J. Siepmann and N. A. Peppas, "Modeling of Drug Release from Delivery Systems Based on Hydroxypropyl Methylcellulose (HPMC)," Advanced Drug Delivery Reviews, Vol. 48, No. 2-3, 2001, pp. 139-157. doi:10.1016/S0169-409X(01)00112-0

[142] R. Bettini, P. Colombo, G. Massimo, P. L. Catellani and T. Vitali, "Swelling and Drug Release in Hydrogel Matrices: Polymer Viscosity and Matrix Porosity Effects," European Journal of Pharmaceutical Sciences, Vol. 2, No. 3, 1994, pp. 213-219. doi:10.1016/0928-0987(94)90025-6

[143] P. L. Ritger and N. A. Peppas, “A Simple Equation for Description of Solute Release I. Fickian and Non-Fickian Release from Non-Swellable Devices in the Form of Slabs, Spheres, Cylinders or Discs,” Journal of Controlled Release, Vol. 5, No. 1 1987, pp. 23-36. doi:10.1016/0168-3659(87)90034-4

[144] N. A. Peppas, “Analysis of Fickian and non-Fickian Drug Release from Polymers,” Pharmaceutica Acta Helvetiae, Vol. 60, No. 4, 1985, pp. 110-111.

[145] D. G. Kanjickal and S. T. Lopina, "Modeling of Drug Release from Polymeric Delivery Systems-A Review," Critical Reviews in Therapeutic Drug Carrier Systems, Vol. 21, No. 5, 2004, pp. 345-386. doi:10.1615/CritRevTherDrugCarrierSyst.v21.i5.10

[146] T. Nagai and Y. Machida, "Buccal Delivery Systems Using Hydrogels,” Advanced Drug Delivery Reviews, Vol. 11, No. 1-2, 1993, pp. 179-191. doi:10.1016/0169-409X(93)90032-Y

[147] M. M. Veillard, M. A. Longer, T. W. Martens and J. R. Robinson, "Preliminary Studies of Oral Mucosal Delivery of Peptide Drugs,” Journal of Controlled Release, Vol. 6, No. 1, 1987, pp. 123-131. doi:10.1016/0168-3659(87)90070-8

[148] M. J. Rathbone and I. G. Tucker, “Mechanisms, Barriers and Pathways of Oral Mucosal Drug Permeation," Advanced Drug Delivery Reviews, Vol. 12, No. 1-2, 1993, pp. 41-60. doi:10.1016/0169-409X(93)90040-B

[149] R. Anders and H. P. Merkle, "Evaluation of Laminated Muco-Adhesive Patches for Buccal Drug Delivery," International Journal of Pharmaceutics, Vol. 49, No. 3, 1989, pp. 231-240. doi:10.1016/0378-5173(89)90347-5

[150] J. D. Smart, “Drug Delivery Using Buccal-Adhesive Systems," Advanced Drug Delivery Reviews, Vol. 11, No. 3, 1993, pp. 253-270. doi:10.1016/0169-409X(93)90012-S

[151] C. A. L. Bourlais, L. Treupel-Acar, C. T. Rhodes, P. A. Sado and R. Leverge, "New Ophthalmic Drug Delivery Systems,” Drug Development and Industrial Pharmacy, Vol. 21, No. 1, 1995, pp. 19-59.

[152] H. W. Hui and J. R. Robinson, "Ocular Delivery of Progesterone Using a Bioadhesive Polymer," International Journal of Pharmaceutics, Vol. 26, No. 3, 1985, pp. 203213. doi:10.1016/0378-5173(85)90230-3

[153] S. Cohen, E. Lobel, A. Trevgoda and Y. Peled, “A Novel in Situ-Forming Ophthalmic Drug Delivery System from Alginates Undergoing Gelation in the Eye," Journal of Controlled Release, Vol. 44, No. 2-3, 1997, pp. 201-208. doi:10.1016/S0168-3659(96)01523-4

[154] J. Carlfors, K. Edsman, R. Petersson and K. Jörnving, "Rheological Evaluation of Gelrite ${ }^{\circledR}$ in Situ Gels for Ophthalmic Use,” European Journal of Pharmaceutical Sciences, Vol. 6, No. 2, 1998, pp. 113-119. doi:10.1016/S0928-0987(97)00074-2

[155] P. Chetoni, G. Di Colo, M. Grandi, M. Morelli, M. F. Saettone and S. Darougar, "Silicone Rubber/Hydrogel Composite Ophthalmic Inserts: Preparation and Preliminary in Vitro/in Vivo Evaluation," European Journal of Pharmaceutical Sciences, Vol. 46, No. 1, 1998, pp. 125132. doi:10.1016/S0939-6411(97)00168-9

[156] S. Türker, E. Onur and Y. Ózer, "Nasal Route and Drug Delivery Systems," Pharmacy World \& Science, Vol. 26, No. 3, 2004, pp. 137-142. doi:10.1023/B:PHAR.0000026823.82950.ff

[157] M. Zhou and M. D. Donovan, "Intranasal Mucociliary Clearance of Putative Bioadhesive Polymer Gels,” International Journal of Pharmaceutics, Vol. 135, No. 1-2, 1996, pp. 115-125. doi:10.1016/0378-5173(96)04441-9

[158] L. Illum, N. F. Farraj and S. S. Davis, "Chitosan as a Novel Nasal Delivery System for Peptide Drugs,” Pharmaceutical Research, Vol. 11, No. 8, 1994, pp. 11861189. doi:10.1023/A:1018901302450

[159] K. Nakamura, Y. Maitani, A. M. Lowman, K. Takayama, N. A. Peppas and T. Nagai, "Uptake and Release of Budesonide from Mucoadhesive, $\mathrm{pH}$-Sensitive Copolymers and Their Application to Nasal Delivery,” Journal of Controlled Release, Vol. 61, No. 3, 1999, pp. 329-335. doi:10.1016/S0168-3659(99)00150-9

[160] Y. M. Sun, J. J. Huang, F. C. Lin and J. Y. Lai, “Composite Poly(2-Hydroxyethyl Methacrylate) Membranes as Rate-Controlling Barriers for Transdermal Applications," Biomaterials, Vol. 18, No. 7, 1997, pp. 527-533. doi:10.1016/S0142-9612(96)00166-4

[161] J. C. Gayet and G. Fortier, "High Water Content BSA- 
PEG Hydrogel for Controlled Release Device: Evaluation of the Drug Release Properties," Journal of Controlled Release, Vol. 38, No. 2-3, 1996, pp. 177-184. doi:10.1016/0168-3659(95)00118-2

[162] B. J. Bellhouse and M. A. F. Kendall, "Dermal Powder Ject Device,” In: M. J. Rathbone, J. Hadgraft and M. S. Roberts, Eds., Modified-Release Drug Delivery Technology, Marcel Dekker, New York, 2003.

[163] M. R. Prausnitz, S. Mitragotri and R. Langer, “Current
Status and Future Potential of Transdermal Drug Delivery," Nature Reviews Drug Discovery, Vol. 3, No. 2, 2004, pp. 111-124.

[164] S. Mehier-Humbert, R. H. Guy, "Physical Methods for Gene Transfer: Improving the Kinetics of Gene Delivery into Cells,” Advanced Drug Delivery Reviews, Vol. 57, No. 5, 2005, pp. 733-753. doi:10.1016/j.addr.2004.12.007. 